\title{
Grammatical Gender Processing in French as a First and a Second Language
}

Thèse dirigée par Cheryl Frenck-Mestre, Holly Branigan (University of Edinburgh) et Ellen Bard (University of Edinburgh), soutenue le 29 février 2008

Le traitement du genre grammatical en français, langue première et seconde

\section{Alice Foucart}

\section{(2) OpenEdition}

Electronic version

URL: https://journals.openedition.org/tipa/342

DOI: $10.4000 /$ tipa.342

ISSN: 2264-7082

\section{Publisher}

Laboratoire Parole et Langage

Printed version

Date of publication: 1 June 2008

ISSN: 1621-0360

\section{Electronic reference}

Alice Foucart, "Grammatical Gender Processing in French as a First and a Second Language", TIPA. Travaux interdisciplinaires sur la parole et le langage [Online], 27 | 2008, Online since 04 December 2012 connection on 08 September 2021. URL: http://journals.openedition.org/tipa/342 ; DOI: https:// doi.org/10.4000/tipa.342

This text was automatically generated on 8 September 2021.

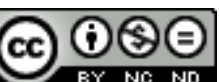

La revue TIPA. Travaux interdisciplinaires sur la parole et le langage est mise à disposition selon les termes de la licence Creative Commons Attribution - Pas d'Utilisation Commerciale - Pas de Modification 4.0 International. 


\title{
Grammatical Gender Processing in French as a First and a Second Language
}

Thèse dirigée par Cheryl Frenck-Mestre, Holly Branigan (University of Edinburgh) et Ellen Bard (University of Edinburgh), soutenue le 29 février 2008

Le traitement du genre grammatical en français, langue première et seconde

\author{
Alice Foucart
}

1 The present thesis investigates grammatical gender processing in French as a first and second language. It focuses mainly on whether non-native speakers can achieve nativelike representation and processing of gender, and whether the native language (L1) influences the acquisition of the second language (L2).

2 Theoretical linguistic models have made two contrasting assumptions concerning the ability of late bilinguals to acquire grammatical gender in their L2. While some models propose that grammatical features, such as gender, are no longer available for L2 acquisition if they are not present in L1 (Hawkins \& Chan, 1997), others assume that these features are still available via the universal grammar if required in the L2 (Schwartz \& Sprouse, 1996; White, 1989, 2003). These assumptions, however, are supported only by off-line studies and do not provide a comprehensive account for gender representation and processing. The present thesis uses online techniques to address these questions both in language comprehension and language production.

3 The first chapters are devoted to comprehension processes and examined French native speakers, English-French and German-French bilinguals' performance during the processing of correct and syntactically anomalous sentences, using ERPs and eyemovements to record behaviour. We concluded that, like native speakers, EnglishFrench bilinguals are sensitive to gender agreement violations. Thus, we argue that late bilinguals are able to acquire the gender system of their L2 even if this grammatical feature is not present in their L1. On the other hand, the performance of the German 
speakers we tested suggests that the presence of a competing gender system in the native language may hamper gender acquisition in L2. The influence of the native language may vary, however, according to both proficiency and how gender systems map across languages, as suggest the results we obtained with Spanish bilinguals tested in language production.

In a second series of experiments, we examined determiner selection in French to further investigate gender representation and processing, but in language production. Using a picture-word interference paradigm, we compared the production of simple and complex noun phrases (NP) in French native speakers, English-French and SpanishFrench bilinguals. From our results, we argue that gender representation is similar in L1 and L2, but that gender processing is less incremental in non-native speakers in that they do not compute agreement between the noun and other elements of the NP as automatically as native speakers do. The absence of interference between the two gender systems of the Spanish-French bilinguals we tested suggests that the gender systems of the two languages may be autonomous in highly proficient bilinguals.

5 Our results suggest that highly proficient bilinguals can reach native-like representation and processing of gender in their L2 and that such is not constrained by either the age of onset of learning or the grammar of the learners L1.

6 La présente thèse est consacrée à l'étude du traitement du genre grammatical en français langue première et seconde (L2). Son but principal est d'examiner la possibilité pour les locuteurs non natifs d'acquérir une représentation et un traitement du genre similaire à celui des locuteurs natifs, et d'évaluer l'influence de la L1 sur la L2.

Certains modèles linguistiques ont proposé deux alternatives contrastées concernant la capacité des bilingues tardifs à acquérir le genre grammatical dans leur L2. Alors que certains modèles proposent que les traits grammaticaux, tels que le genre, ne sont plus disponibles pour l'acquisition d'une L2 s'ils ne sont pas présents dans la L1 (Hawkins \& Chan, 1997), d'autres supposent que ces traits sont toujours disponibles via la grammaire universelle s'ils sont nécessaires en L2 (Schwartz \& Sprouse, 1996; White, 1989, 2003). Ces alternatives ne sont cependant soutenues que par des études off-line et ne fournissent pas d'explications complètes en ce qui concerne la représentation et le traitement du genre. Ce travail utilise des techniques on-line afin de faire porter ces questions aussi bien sur la compréhension que sur la production de langage.

Les premiers chapitres sont consacrés aux processus impliqués dans la compréhension $\mathrm{du}$ langage. Ils comparent la performance des locuteurs natifs à celle des bilingues anglais-français et allemand-français lors du traitement de phrases syntaxiquement correctes et incorrectes, à l'aide des techniques de potentiels évoqués et de mouvements oculaires. Les expériences présentées dans ces chapitres ont révélé que, tout comme les locuteurs natifs, les anglophones sont sensibles aux violations d'accord en genre en français. Ainsi, nous avançons que les bilingues tardifs dont la L1 ne possède pas le genre sont néanmoins capables d'acquérir un système de genre dans leur L2. En revanche, la performance des germanophones testés lors des expériences suggère que la présence d'un système de genre en L1 peut perturber l'acquisition d'un tel système en L2. Cependant, il semble que l'influence de la langue maternelle puisse varier en fonction de la compétence ainsi que de la proximité des systèmes dans les 
deux langues comme le suggèrent les résultats obtenus avec les hispanophones testés lors de la production d'énoncés en français.

Dans une seconde série d'expériences concernant la production de langage, la sélection du déterminant en français a été examinée afin d'approfondir l'étude de la représentation et du traitement du genre. La production de groupes nominaux simples et complexes chez les Français natifs et les bilingues anglais-français et espagnolfrançais a été comparée à l'aide du paradigme d'interférence image-mot. D'après les résultats, il semble que la représentation du genre soit similaire en $\mathrm{L} 1$ et $\mathrm{L} 2$, mais que le traitement soit moins automatique chez les bilingues que chez les locuteurs natifs. L'absence d'interférence entre les deux systèmes de genre chez les bilingues espagnolfrancais que nous avons testés laisse à penser que les systèmes des deux langues pourraient être autonomes chez les bilingues avancés.

Nos résultats semblent montrer que les bilingues avancés peuvent acquérir une représentation et un traitement du genre dans leur L2, similaires à celui des locuteurs natifs, et ce indépendamment de l'âge auquel l'apprentissage commence ou de la grammaire de la L1.

\section{INDEX}

Keywords: grammatical gender, second language acquisition, ERP, production and comprehension of language, psycholinguistics

Mots-clés: genre grammatical, acquisition d'une seconde langue, ERP, production et compréhension de langage, psycholinguistique 